\title{
Metastatic Lung Non-Small Cell Squamous Carcinoma
}

National Cancer Institute

\section{Source}

National Cancer Institute. Metastatic Lung Non-Small Cell Squamous Carcinoma. NCI

Thesaurus. Code C157364.

A squamous non-small cell carcinoma that arises from the lung and has metastasized to another anatomic site. 